\title{
Transition Care for Children With Special Health Care Needs
}

WHAT'S KNOWN ON THIS SUBJECT: More children with special health care needs are surviving to adulthood and entering the adult health care system. Effective transition of care can promote continuity of developmental and age-appropriate care for these individuals.

WHAT THIS STUDY ADDS: Existing studies provide modest transition care support. Methods for providing transition care warrant attention, and future research needs are wide ranging. Consistent and accepted measures of transition success are critical to establishing an adequate body of literature to affect practice.

\section{abstract}

BACKGROUND: Approximately 750000 children in the United States with special health care needs will transition from pediatric to adult care annually. Fewer than half receive adequate transition care.

METHODS: We had conversations with key informants representing clinicians who provide transition care, pediatric and adult providers of services for individuals with special health care needs, policy experts, and researchers; searched online sources for information about currently available programs and resources; and conducted a literature search to identify research on the effectiveness of transition programs.

RESULTS: We identified 25 studies evaluating transition care programs. Most $(n=8)$ were conducted in populations with diabetes, with a smaller literature $(n=5)$ on transplant patients. We identified an additional 12 studies on a range of conditions, with no more than 2 studies on the same condition. Common components of care included use of a transition coordinator, a special clinic for young adults in transition, and provision of educational materials.

CONCLUSIONS: The issue of how to provide transition care for children with special health care needs warrants further attention. Research needs are wide ranging, including both substantive and methodologic concerns. Although there is widespread agreement on the need for adequate transition programs, there is no accepted way to measure transition success. It will be essential to establish consistent goals to build an adequate body of literature to affect practice. Pediatrics 2014;134:900-908
AUTHORS: Alaina M. Davis, MD, , Rebekah F. Brown, MD, ${ }^{\mathrm{b}, \mathrm{c}}$ Julie Lounds Taylor, PhD, MA, a,b,d Richard A. Epstein, PhD, $\mathrm{MPH}^{\mathrm{b}, \mathrm{e}}$ and Melissa L. McPheeters, PhD, MPH ${ }^{\mathrm{b}, \mathrm{f}}$

aDivision of General Pediatrics, and 'Division of Allergy, Immunology and Pulmonary Medicine, Department of Pediatrics, ${ }^{e}$ Division of Child and Adolescent Psychiatry, Department of Psychiatry; and fDepartment of Health Policy, Vanderbilt University School of Medicine, Nashville, Tennessee; 'bvidenceBased Practice Center, Institute for Medicine and Public Health, Vanderbilt University Medical Center, Nashville, Tennessee; and ${ }^{a}$ Vanderbilt University Kennedy Center for Research on Education and Human Development, Nashville, Tennessee

\section{KEY WORDS}

special health care needs, transition to adult care, self-management, adolescent health services

\section{ABBREVIATIONS}

CSHCN — children with special health care needs HbA1c-glycosylated hemoglobin

Drs Davis, Brown, Taylor, Epstein, and McPheeters assisted with conceptualizing and designing the study, analyzing studies identified, drafting the report and manuscript, and reviewing and revising the manuscript; all authors approved the final manuscript as submitted.

The authors of this report are responsible for its content. Statements in the report should not be construed as endorsement by the Agency for Healthcare Research and Quality or the US Department of Health and Human Services.

www.pediatrics.org/csi/doi/10.1542/peds.2014-1909

doi:10.1542/peds.2014-1909

Accepted for publication Aug 12, 2014

Address correspondence to Melissa L. McPheeters, PhD, MPH, Vanderbilt Evidence-based Practice Center, Institute for Medicine and Public Health, Vanderbilt University Medical Center, Nashville, TN 37203-1738. E-mail: melissa.mcpheeters@vanderbilt.edu PEDIATRICS (ISSN Numbers: Print, 0031-4005; Online, 1098-4275) Copyright (C) 2014 by the American Academy of Pediatrics FINANCIAL DISCLOSURE: All authors received support from Contract No. 290-2012-00009-I from the Agency for Healthcare Research and Quality, US Department of Health and Human Services. Dr Taylor was supported by a career development award from the National Institute of Mental Health (K01 MH092598, Taylor, PI). The other authors have indicated they have no financial relationships relevant to this article to disclose.

(Continued on last page) 
Effective transition from pediatric to adult health care is intended to ensure continuity of developmental and ageappropriate care for all patients, including children with special health care needs (CSHCN). As a result of the increasing prevalence of childhood chronic conditions and life expectancy for $\mathrm{CSHCN}, 1,2$ estimates now suggest $~ 750000 \mathrm{CSHCN}$ transition to adult care annually. 3,4

There is conceptual agreement that transition involves more than the "transfer" of care and optimally begins before the point of transfer and that transitions from pediatric to adult care can be associated with adverse health outcomes. ${ }^{5-12}$ Fewer than $50 \%$ of CSHCN aged 12 to 17 years indicate they received adequate support and services for their transition to adult care, ${ }^{13-16}$ and ethnic minorities and children living in poverty appear to be at significantly increased risk for suboptimal care during this period. ${ }^{17,18}$ The low rates of transition support reported by families may reflect the fact that only one-third of pediatricians report making referrals to adult physicians, and $<15 \%$ report providing transition education materials. ${ }^{19}$

Despite reasonably strong conceptual agreement on the importance of transition for CSHCN, there is a lack of rigorous research. Because there are limited data and too few research studies to support a full systematic review of this emerging intervention, we conducted interviews with experts in the field and searched sources of published and gray literature on the topic. This work was funded by the Agency for Healthcare Research and Quality. In this article, we summarize findings from the published literature evaluating transition care programs. The full report is available at $h t t p: / /$ www.effectivehealthcare.ahrq.gov.

\section{METHODS}

We had discussions with key informants and searched the published and "gray" literature. In consultation with the investigative team and the Agency for
Healthcare Research and Quality, we assembled a list of individuals representing a clinical, policy, research, or advocate perspective for transition care. We held 1 group discussion with these key informants by telephone to help refine our a priori guiding questions.

We used controlled vocabulary terms and key words to search the published literature for studies that evaluated transition programs 2000 to 2013 and reviewed the reference lists of retrieved publications for other relevant publications. We augmented the searches in bibliographic databases by searching for gray literature from the Internet, government Web sites, clinical trial databases, trade publications, and meeting abstracts. We did not limit our search by clinical condition, but we did limit by type of care, excluding studies of transition care in the context of palliative or hospice care. We also limited our search for empirical articles to those evaluating transition care programs. Table 1 summarizes the inclusion and exclusion criteria for the evaluation studies that were included in the empirical literature review.

\section{RESULTS}

\section{Patients and Conditions}

Represented in Evaluation Studies

Of the 699 articles reviewed, we identified 25 studies ${ }^{20-44}$ reported in 30 publications ${ }^{20-49}$ that evaluated a system of purposeful transition care from the peer-reviewed literature.

We included studies of any approach to transition care even if the evaluation outcome was defined as successful transfer or if the system focused primarily on the transfer process. To be clear, we use the term "transfer" generally to describe the point-in-time when a case is transferred from pediatric to adult care, and we use the term "transition" to communicate a more comprehensive set of support processes and care that ideally begin before and extend after transfer.

Among the 25 studies, 8 studied transition care for adolescents with diabetes, ${ }^{27-32,39,40} 5$ studied adolescents who had undergone organ transplant ${ }^{22,23,26,33,34}$ (all but 1 of these focused on kidney transplant), and 2 studied adolescents with sickle cell disease $^{36,41}$ The remainder studied a variety of conditions including congenital adrenal hyperplasia, ${ }^{21}$ HIV, ${ }^{24}$ epilepsy, ${ }^{25}$ juvenile idiopathic arthritis, ${ }^{38}$ spina bifida, ${ }^{42}$ cystic fibrosis, ${ }^{37}$ or inflammatory bowel disease ${ }^{43}$ or included a patient population comprising $>1$ chronic disease. ${ }^{20,35,44}$ Twelve studies were conducted in Europe: 8 in the United Kingdom, 21,22,29,32,35,36,39,50 1 in Germany, ${ }^{33} 1$ in Spain, ${ }^{40}$ and 2 in

TABLE 1 Inclusion and Exclusion Criteria for Evaluation Studies

\begin{tabular}{ll}
\hline \multicolumn{1}{c}{ Category } & \multicolumn{1}{c}{ Criteria } \\
\hline Study population & Children with special health care needs \\
Publication languages & English only \\
Admissible evidence (study design & Admissible designs \\
and other criteria) & Randomized controlled trials (including wait-list control), cohorts \\
& with comparison, pre-post cohort without comparison, stepped \\
& wedge designs, case-control, case series, and case reports \\
& Other criteria \\
Original research studies that provide sufficient detail regarding \\
methods and results to enable use and adjustment of the data and \\
results \\
Studies must address the following for transitions in care: \\
Transitions of care from pediatric to adult services \\
CSHCN as defined by the American Academy of Pediatrics \\
A special health need that arises from a chronic physical, \\
developmental, or intellectual condition or disability
\end{tabular}


Italy. ${ }^{27,31}$ Eight studies were conducted in the United States $20,28,34,36,37,41,42,44 ; 3$ studies were conducted in Canada $23,25,45$; and 1 study was conducted in Australia. ${ }^{26}$ One study included data from the United Kingdom and Australia. ${ }^{24}$

Few studies used a concurrent comparison group. Some studies compared survey responses of individuals who had participated in transition care with those of individuals who had not, with transition generally not occurring concurrently. Because most interventions are implemented at the system level and are provided to all relevant patients at the same time, these studies generally relied on data from individuals who transitioned before the services were available as comparators to the intervention group.

Outcomes were generally patientreported and focused on issues such as satisfaction with the process or health-related quality of life. Some clinical outcomes are available in the literature; these include objective measures such as glycosylated hemoglobin (HbA1c) levels for patients with diabetes and rates of organ rejection among transplant patients. Generally, however, studies defined successful transition as attendance in adult care (eg, successful transfer) or continued medication adherence. Thus, although most of the described programs offered comprehensive support rightly regarded as "transition care," evaluation of these programs often focused on outcomes traditionally regarded as indices of the more limited concept of "transfer."

In addition to the evaluation information on transition care for youth with special health needs that we found in the indexed literature, we also cataloged relevant transition care resources, programs, and projects found in the gray literature. A detailed list of projects and resources can be found in the full report.
Length of Follow-up and Outcomes Measured in Evaluation Studies

\section{Diabetes}

The most commonly studied group of transitioning youth was individuals with diabetes (Table 2) . ${ }^{27-32,39,40}$

Interventions included use of a transition coordinator $(n=2),{ }^{27,29}$ attendance of the pediatrician at the adult care visit(s) $(n=2),{ }^{27,31}$ education and skill building $(n=3), 28,39,40$ a specialized young adult clinic $(n=4), 28,29,32,39$ and use of technology for education and reminders $(n=2){ }^{29,30}$ In 5 models, patients transferred directly into an adult clinic. ${ }^{27,30-32,40}$ Two programs used practical assistance with scheduling. 29,40 No 2 studies evaluated the same transition intervention, although some intervention components were common across studies.

The most common diabetes-related outcomes were HbA1c levels (a marker for glycemic control), ${ }^{32}$ diabetes-related hospitalizations, ${ }^{29,30}$ and adult service attendance. ${ }^{27,30-32}$ Seven studies used HbA1c levels as outcomes. ${ }^{27-29,31,32,39,40}$ Patient satisfaction was the focus of 2 studies. ${ }^{27,31}$

Five studies included some sort of comparison group, 27,28,30,32,39 with 3 using concurrent comparators, ${ }^{27,28,32}$ although the analyses were retrospective. Three studies did not use a comparison group. 29,31,40 Most studies were published as quality improvement evaluations and reported either improved health outcomes or maintenance of health.

\section{Solid Organ Transplant}

A small body of literature $22,23,26,33,34$ is available on the transition of pediatric patients with organ transplants to adult care (Table 3). Four of the 5 studies $22,23,26,33$ focus on kidney transplant patients, with the remaining study ${ }^{34}$ on liver transplant. All of the studies on kidney transplant patients include the evaluation of a specific transition-oriented clinic - either one for youth alone or a joint pediatric-adult clinic. The 1 study on liver transplant patients evaluated the role of a transition coordinator.34 This was the only prospective study, but the study did not use a concurrent control group, relying on historical comparators who had transitioned before implementation of the coordinator role. ${ }^{34}$ The four studies on kidney transplant patients report clinical outcomes, including organ rejection and mortality.22,23,26,33 The study on liver transplant patients reports on patient satisfaction, psychological benefits, and medication adherence, confirmed via blood draw. ${ }^{34}$ Although some studies reported improved rates of organ rejection and medication adherence, others reported clinical worsening.

\section{Other Conditions.}

We identified an additional 12 studies $^{20,21,24,25,35-38,41-44}$ on a range of conditions (Table 4). Three studies included patients with a variety of conditions, $, 0,35,44$ and 2 studies focused on sickle cell disease ${ }^{36,41}$; the remainder of the studies had 1 clinical focus. ${ }^{21,24,25,37,38,42,43}$ The transition care programs evaluated in these studies included use of a transition coordinator, ${ }^{37,38}$ multidisciplinary teams to provide care jointly, 24,35,37,41,43 and a separate young adult clinic. ${ }^{21}$ One transition intervention provided direct scheduling of visits, ${ }^{36}$ one was a mentoring group that met over 10 months, ${ }^{20}$ and the other used a generic 2-month intensive Internet- and text-messagebased intervention followed by a 6month review period. ${ }^{44}$ Patient education was a common component of transition. 20,25,37,38,41-44 Although many of these studies report positive results, the range of clinical conditions, transition care programs, and evaluation designs precludes making definitive conclusions.

\section{DISCUSSION}

Despite identifying numerous descriptions of existing transition programs or services, we identified only 25 empirical 
TABLE 2 Overview of Diabetes Transition Studies

\begin{tabular}{|c|c|c|c|}
\hline Citation (Location) & Design $^{a}$ & Transition Care Elements & Summary of Findings \\
\hline $\begin{array}{l}\text { Cadario et al } 2009^{27} \\
\text { (Italy) }\end{array}$ & $\begin{array}{l}\text { Retrospective } \\
\text { cohort }\end{array}$ & $\begin{array}{l}\text { - Transition coordinator } \\
\text { - Structured transfer plan } \\
\text { - Pediatrician attendance at the adult care visit }\end{array}$ & $\begin{array}{l}\text { Shorter transition; better clinic attendance; } \\
\text { lower HbA1c; favorable experience }\end{array}$ \\
\hline $\begin{array}{l}\text { Gholap et al } 2006^{39} \\
\text { (United Kingdom) }\end{array}$ & Other & $\begin{array}{l}\text { - Patient education and skill building } \\
\text { - Specialized transition clinic (Young Persons } \\
\text { Clinic) } \\
\text { - Alphabet mnemonic approach to care }\end{array}$ & $\begin{array}{l}\text { Better clinic attendance; lower HbA1c; higher } \\
\text { screening rates for nephropathy; lower rates } \\
\text { of nephropathy }\end{array}$ \\
\hline $\begin{array}{l}\text { Holmes-Walker et al } 2007^{29} \\
\quad \text { (Australia) }\end{array}$ & Other & $\begin{array}{l}\text { - Transition coordinator } \\
\text { - Specialized transition clinic (Transition } \\
\text { Support Program) } \\
\text { - Patient education; technology for education } \\
\quad \text { and reminders }\end{array}$ & $\begin{array}{l}\text { Lower HbA1c; better attendance; decrease in } \\
\text { diabetic ketoacidosis admissions }\end{array}$ \\
\hline $\begin{array}{l}\text { Kipps et al } 2002^{32} \\
\text { (United Kingdom) }\end{array}$ & $\begin{array}{l}\text { Retrospective } \\
\text { cohort }\end{array}$ & $\begin{array}{l}\text { - Specialized transition clinic (initial move to an } \\
\text { adolescent clinic before moving to an adult } \\
\text { clinic) } \\
\text { - Introduction to the adult provider before } \\
\text { transfer }\end{array}$ & $\begin{array}{l}\text { Posttransfer clinic attendance was highest in the } \\
\text { districts in which patients met the adult } \\
\text { provider pretransfer }\end{array}$ \\
\hline $\begin{array}{l}\text { Lane et al } 2007^{28} \\
\quad \text { (United States) }\end{array}$ & $\begin{array}{l}\text { Retrospective } \\
\text { cohort }\end{array}$ & $\begin{array}{l}\text { - Patient education and skill building } \\
\text { - Specialized young adult clinic }\end{array}$ & $\begin{array}{l}\text { HbA1c levels did not change in either clinic } \\
\text { overall; Decrease in HbA1c levels larger in } \\
\text { patients from the young adult clinic for } \\
\text { subgroup with the highest levels of HbA1c }\end{array}$ \\
\hline $\begin{array}{l}\text { Van Wallegham et al } 2006^{30} \\
\text { (Canada) }\end{array}$ & $\begin{array}{l}\text { Prospective } \\
\text { cohort }\end{array}$ & $\begin{array}{l}\text { - Systems navigator model with administrative } \\
\text { coordinator } \\
\text { - Patient education; technology for education } \\
\text { and reminders }\end{array}$ & $\begin{array}{l}\text { Higher dropout rate ( } 40 \%) \text { among individuals } \\
\text { without access to navigator compared with } \\
11 \% \text { of individuals with access. }\end{array}$ \\
\hline $\begin{array}{l}\text { Vanelli et al } 2004^{31} \\
\text { (Italy) }\end{array}$ & Other & $\begin{array}{l}\text { - Protocol for an uninterrupted transfer } \\
\text { - Pediatrician attendance at the adult care visit }\end{array}$ & $\begin{array}{l}\text { Higher patient satisfaction; improvement in } \\
\text { HbA1c levels at 1-year posttransition }\end{array}$ \\
\hline $\begin{array}{l}\text { Vidal et al } 2004^{40} \\
\quad \text { (Spain) }\end{array}$ & Other & - Patient education and skill building & $\begin{array}{l}\text { Decrease in } \mathrm{HbA} 1 \mathrm{c} \text { and in the number of } \\
\text { hypoglycemic episodes }\end{array}$ \\
\hline
\end{tabular}

a Design types are classified as randomized controlled trial, prospective cohort, retrospective cohort, and other.

evaluation studies, only 2 of which were randomized controlled trials. Because most transition care interventions are implemented at the system level and are delivered to all relevant patients at the same time, few of the studies included a concurrent comparison group; most of the studies relied on data from patients who transitioned before the transition-specific services were available as comparators.

Common components of care included educational materials, sometimes using computer-based programming, a special clinic for young adults in transition, and the use of a transition coordinator. Outcomes were generally patient-reported and focused mostly on issues such as satisfaction with the transition process or health-related quality of life, but also include objective measures such as $\mathrm{HbA1C}$ levels for patients with diabetes and rates of organ rejection among transplant patients. Generally, however, successful transition is defined as attendance in adult care (transfer) or continued adherence to medication. Thus, although the programs offered comprehensive support rightly regarded as transition care, evaluation outcomes focused (at least in large part) on outcomes traditionally regarded as an index of the more limited concept of transfer.

Future research must address both methodologic and substantive issues. Methods issues include the need for a common and validated definition of transition success, more rigorous study designs, dedicated funding, and inclusion of a broader range of clinical research perspectives (ie, involvement of pediatric and adult researchers). The lack of well-defined outcome measures is a major barrier. ${ }^{51-54}$ Possible metrics to evaluate success could include clinician, adolescent, and parent perception of success and satisfaction with the transition process, improved or stable disease-specific medical outcomes, ${ }^{55,56}$ decreased or stable cost of health care, or educational milestones in patients' ability to care for themselves or navigate the health care setting. ${ }^{54,57,58}$ Without clear clinical or functional outcomes identified, most studies have focused on qualitative measures including clinicians' or patients' perceptions of success without objective measurements to support the claims of success of individual transition processes. No validated measures of transition have been developed. ${ }^{51}$

Future methodologic research should focus on identifying or developing objective measures of successful transition as well as transition tools. ${ }^{59,60}$ Quality-of-life and personalized outcomes identified by the adolescents participating in transition care could be significant outcome measures, but others should be developed as well.51,52,54,61,62 In addition, few studies provided data on 
TABLE 3 Overview of Transplant Transition Studies

\begin{tabular}{|c|c|c|c|}
\hline Citation (Location) & Design $^{a}$ & Transition Care Elements & Summary of Findings \\
\hline $\begin{array}{l}\text { Annunziato et al } 2013^{34} \\
\quad \text { (United States) }\end{array}$ & Other & - Transition coordinator & $\begin{array}{l}\text { Improved medication adherence for patients } \\
\text { with access to the transition coordinator }\end{array}$ \\
\hline $\begin{array}{l}\text { Chaturvedi et al } 2009^{26} \\
\text { (Australia) }\end{array}$ & Other & $\begin{array}{l}\text { - Specialized transition clinic } \\
\text { - Patient education }\end{array}$ & $\begin{array}{l}\text { No change in organ rejection; medication } \\
\text { adherence worsened after care transfer }\end{array}$ \\
\hline $\begin{array}{l}\text { Harden et al } 2012^{22} \text { and } 2013^{48} \\
\text { (United Kingdom) }\end{array}$ & Other & $\begin{array}{l}\text { - Specialized transition clinic } \\
\text { - Joint pediatric and young adult } \\
\text { provider visits }\end{array}$ & $\begin{array}{l}\text { Lower organ rejection in patients with access } \\
\text { to the transition clinic }\end{array}$ \\
\hline $\begin{array}{l}\text { Pape et al } 2013^{33} \\
\text { (Germany) }\end{array}$ & Retrospective cohort & - Specialized transition clinic & $\begin{array}{l}\text { No change in clinical outcomes; patient } \\
\text { satisfaction was higher with transition } \\
\text { clinic }\end{array}$ \\
\hline $\begin{array}{l}\text { Prestidge et al } 2012^{23} \\
\quad \text { (Canada) }\end{array}$ & Other & $\begin{array}{l}\text { - Specialized transition clinic } \\
\text { (Transition Clinic) }\end{array}$ & $\begin{array}{l}\text { Lower organ rejection and death in patients } \\
\text { with access to the transition clinic; lower cost }\end{array}$ \\
\hline
\end{tabular}

a Design types are classified as randomized controlled trial, prospective cohort, retrospective cohort, and other.

long-term follow-up, which could be important for considering the ultimate success of transitioning.

Randomization in transition research can be problematic because medical care is multidisciplinary, and isolating any 1 intervention or holding constant concomitant interventions is difficult. $34,35,58,63$ However, rigorous evaluation of multidisciplinary transition programs is needed. Ideal designs would evaluate participants before, during, and after the transition period. These studies would therefore need to be long and thus may be cost-prohibitive. ${ }^{52,58,64,65}$ One method to obtain prospective data for evaluation of transition would be the development of disease-specific or location-specific core transition data sets that could be used for research of the transition process over the short and long terms. ${ }^{58}$ An alternative to using longitudinal studies to evaluate the impact of transition on patient outcomes and assess overall improvement in the transition process is quality improvement initiatives and evaluation designs. ${ }^{66-69}$ Quality improvement research could help identify best practices for transition, 66 factors within transition that affect outcomes positively or negatively, 52,56,57 and individual predictors for successful transition. 52,56

Funding streams generally focus on specific diseases, but the field of transition research would benefit from more generalized research that can identify effective methods across disease groups. Identifying funding streams that are not disease-specific may be challenging but important. ${ }^{58}$

Traditionally, transition efforts and research have been led by pediatric providers even though adult providers are an essential part of the process. Future research should include both pediatric and adult researchers ${ }^{58}$ and require involvement of primary care providers and subspecialty care providers when applicable. No research has identified an optimal timing of transfer when multiple provider specialties are involved in an individual patient's care. Therefore, future research involving primary and subspecialty care providers could help guide which service should transfer first during the transition process and the overall timing of transitions.

Areas and opportunities for future research include technology, information about health care systems, disease progression, patient-specific transition, educational research, and cost research. The use of technology in transition has particular promise for adolescents, who may be more comfortable users of technology than some adults. Novel uses of technology to improve adherence to medications, to provide education regarding their medical disease, to identify medical deterioration earlier, and to communicate with their health care providers should be further considered in future studies. $44,53,58,70$ Some of the disparities in access to care as CSHCN transition to adulthood may be minimized by expansion and evaluation of uses of technology such as telemedicine, text messaging, or social media. ${ }^{44,58}$

Although research focusing on generalizable transition care processes is essential, the development of validated tools to aid a variety of health care systems in implementing successful transition is also necessary. Evaluations of transition care programs will need to specify the type of systems in which the transition was performed and what resources or tools were required to implement the program.

Documentation of resources could include specific programs such as citybased transportation programs and institutional resources such as personnel, educational opportunities, and electronic medical record support. Identifying the differences and similarities within successful transition processes could be beneficial to the medical community as individual clinical systems modify components of the transition processes to work within their systems.

With improved clinical outcomes, many chronic diseases that were formerly seen only in pediatrics are now affecting adults. The adult course of these diseases is largely unknown, and therefore, 


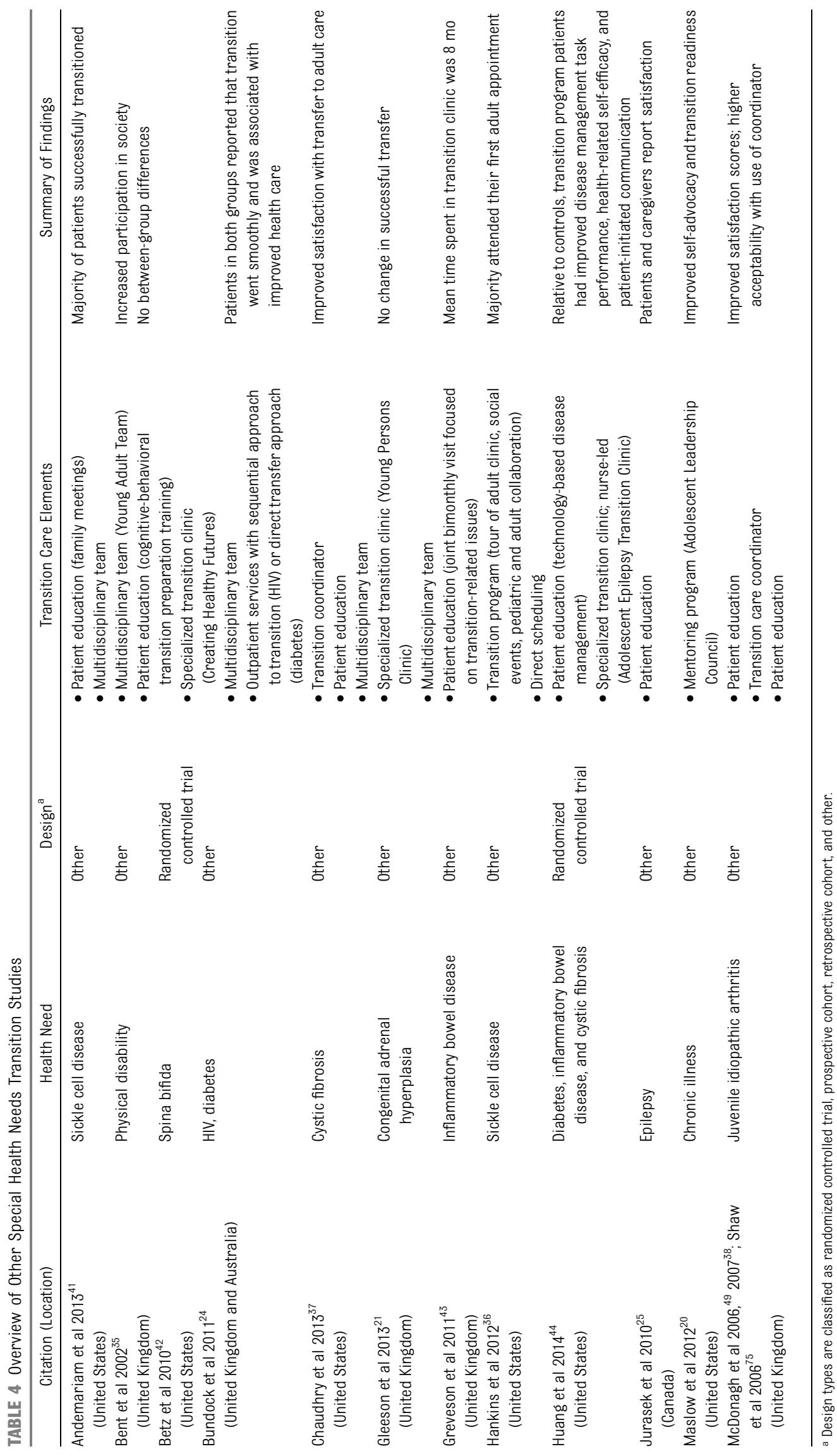


aspects of transition specific for these diseases remain unclear. For these diseases, prospective tracking of the natural course and complications of these diseases will be necessary to determine what components of transition will be required when caring for adults with these diseases. $55,61,63$

Appropriate timing and tools for successful transition may vary by severity or type of disease. Research of transition programs would need to control for these differences in care and outcomes. In addition, the hypothesis that children with different diseases may require different transition processes requires further investigation because no study has evaluated the efficacy of diseasespecific versus general transition processes in a comparative manner.

Intellectual disability can be associated with some chronic diseases that affect children transitioning to adult care. The severity of disability influences the degree with which a young adult can manage his or her own care and therefore affects measures of successful transition. Physical and developmental delays or impairment can affect the ability of individuals to navigate the medical system independently. Transition research needs to include stratification for cognitive ability and developmental delay for

\section{REFERENCES}

1. American Academy of Pediatrics Committee on Children with Disabilities and Committee on Adolescence. Transition of care provided for adolescents with special health care needs. Pediatrics. 1996;98(6 pt 1):12031206

2. Gortmaker SL, Sappenfield W. Chronic childhood disorders: prevalence and impact. Pediatr Clin North Am. 1984;31(1):3-18

3. Goodman DM, Hall M, Levin A, et al. Adults with chronic health conditions originating in childhood: inpatient experience in children's hospitals. Pediatrics. 2011;128 (1):5-13

4. Scal $P$, Ireland M. Addressing transition to adult health care for adolescents with the subjects, if variability exists. Future research efforts should evaluate the success of transition program modifications for patients with cognitive or physical impairments.

Behavioral health care is important in the transition process to provide support and services to address coping with chronic medical diseases and treatment, nonadherence, and psychological effects of their chronic disease. Few studies have addressed this aspect of transition care. Studies evaluating the role of behavioral health within the transition process are critical.

We identified 1 cost study. The study took place in England, so the relevance of the results to the US health care system may be limited. The study identified increased costs associated with the transition period but did not find that an organized transition program was more resource-intensive than ad hoc services. ${ }^{35}$ With future transition research, researchers should attempt to report the costs associated with transition implementation and service. This information can then be compared with the costs of unsuccessful transition in this patient population. 62,65

We note that our search was restricted to articles published in English, and we did not include a review of literature on palliative or hospice care. Although our conclusions are limited by the small number of studies included in the review, the generally poor methodologic quality of the included studies, and difficulties inherent to evaluating complex and multicomponent interventions such as comprehensive transition care programs, we also note that our findings are consistent with those from previous reviews. ${ }^{71-74}$

The issue of how to provide good transition care for CSHCN warrants further attention. The number of CSHCN reaching adulthood is increasing, and the diversity of their clinical conditions is expanding. Future research needs are wide ranging, including both substantive and methodologic improvements. At this time, the field lacks even a consistent and accepted way of measuring transition success, and it will be essential to establish consistent goals to build an adequate body of literature to affect practice.

\section{ACKNOWLEDGMENTS}

Tanya Surawicz contributed to the data collection; Rebecca Jerome contributed to data collection and interpretation; and Shannon Potter designed the data collection instruments, coordinated and supervised data collection, and assisted in the preparation of the manuscript. special health care needs. Pediatrics. 2005; 115(6):1607-1612

5. American Academy of Pediatrics; American Academy of Family Physicians; American College of Physicians-American Society of Internal Medicine. A consensus statement on health care transitions for young adults with special health care needs. Pediatrics. 2002;110(6 pt 2):1304-1306

6. Schober J, Nordenström A, Hoebeke P, et al. Disorders of sex development: summaries of long-term outcome studies. I Pediatr Urol. 2012;8(6):616-623

7. Cooley WC, Sagerman PJ; American Academy of Pediatrics; American Academy of Family Physicians; American College of Physicians;
Transitions Clinical Report Authoring Group. Supporting the health care transition from adolescence to adulthood in the medical home. Pediatrics. 2011;128(1):182-200

8. Ferris ME, Wood D, Ferris MT, et al. Toward evidence-based health care transition: The Health Care Transition Research Consortium. Intl J Child Adolesc Health. 2010;3(4):479-486

9. Rosen DS, Blum RW, Britto M, Sawyer SM, Siegel DM. Transition to adult health care for adolescents and young adults with chronic conditions: position paper of the Society for Adolescent Medicine. J Adolesc Health. 2003;33(4):309-311

10. Webb N, Harden P, Lewis C, et al. Building consensus on transition of transplant 
patients from paediatric to adult healthcare. Arch Dis Child. 2010;95(8):606-611

11. National Center for Health Statistics. Healthy People 2010 Final Review: Disability and secondary conditions (DHHS publication (PHS)2012-1038). Hyattsville, MD: US Department of Health and Human Services; 2012

12. National Center for Health Statistics. The National Survey of Children With Special Health Care Needs Chartbook 2005-2006. Hyattsville, MD: US Department of Health and Human Services Health Resources and Services Administration Maternal and Child Health Bureau; 2006

13. Pollack L, McManus M. Special Analysis of the 2009/10 National Survey of Children With Special Health Care Needs by Lauren Pollack and Margaret McManus of the National Alliance to Advance Adolescent Health. 2012

14. Stoeck PA, Cheng N, Berry AJ, Bazemore AW, Phillips RL Jr. Health care transition counseling for youth with special health care needs. Am Fam Physician. 2012;86(11):1024

15. McManus MA, Pollack LR, Cooley WC, et al. Current status of transition preparation among youth with special needs in the United States. Pediatrics. 2013;131(6):1090-1097

16. Toomey SL, Chien AT, Elliott MN, Ratner J, Schuster MA. Disparities in unmet need for care coordination: the national survey of children's health. Pediatrics. 2013;131(2): 217-224

17. Kane DJ, Kasehagen L, Punyko J, Carle AC, Penziner A, Thorson S. What factors are associated with state performance on provision of transition services to $\mathrm{CSHCN}$ ? Pediatrics. 2009;124(suppl 4):S375-S383

18. Richmond N, Tran T, Berry S. Receipt of transition services within a medical home: do racial and geographic disparities exist? Matern Child Health J. 2011;15(6):742-752

19. Reiss J. Health care transition for emerging adults with chronic health conditions and disabilities. Pediatr Ann. 2012:41(10):429-435

20. Maslow G, Adams C, Willis M, et al. An evaluation of a positive youth development program for adolescents with chronic illness. J Adolesc Health. 2013;52(2):179-185

21. Gleeson H, Davis J, Jones J, O'Shea E, Clayton PE. The challenge of delivering endocrine care and successful transition to adult services in adolescents with congenital adrenal hyperplasia: experience in a single centre over 18 years. Clin Endocrinol (Oxf). 2013;78(1):23-28

22. Harden PN, Walsh G, Bandler N, et al. Bridging the gap: an integrated paediatric to adult clinical service for young adults with kidney failure. BMJ. 2012;344:e3718
23. Prestidge C, Romann A, Djurdjev 0, MatsudaAbedini M. Utility and cost of a renal transplant transition clinic. Pediatr Nephrol. 2012; 27(2):295-302

24. Bundock H, Fidler S, Clarke S, et al. Crossing the divide: transition care services for young people with HIV-their views. AIDS Patient Care STDS. 2011;25(8):465-473

25. Jurasek L, Ray L, Quigley D. Development and implementation of an adolescent epilepsy transition clinic. J Neurosc Nurs. 2010;42(4): 181-189

26. Chaturvedi S, Jones CL, Walker RG, Sawyer SM. The transition of kidney transplant recipients: a work in progress. Pediatr Nephrol. 2009;24(5):1055-1060

27. Cadario F, Prodam F, Bellone S, et al. Transition process of patients with type 1 diabetes (T1DM) from paediatric to the adult health care service: a hospital-based approach. Clin Endocrinol (Oxf). 2009;71(3): 346-350

28. Lane JT, Ferguson A, Hall J, et al. Glycemic control over 3 years in a young adult clinic for patients with type 1 diabetes. Diabetes Res Clin Pract. 2007;78(3):385-391

29. Holmes-Walker DJ, Llewellyn AC, Farrell K. A transition care programme which improves diabetes control and reduces hospital admission rates in young adults with type 1 diabetes aged 15-25 years. Diabet Med. 2007:24(7):764-769

30. Van Walleghem N, MacDonald CA, Dean HJ. Building connections for young adults with type 1 diabetes mellitus in Manitoba: feasibility and acceptability of a transition initiative. Chronic Dis Can. 2006;27(3):130-134

31. Vanelli M, Caronna S, Adinolfi B, Chiari G, Gugliotta M, Arsenio L. Effectiveness of an uninterrupted procedure to transfer adolescents with type 1 diabetes from the paediatric to the adult clinic held in the same hospital: eight-year experience with the Parma protocol. Diabetes Nutr Metab. 2004:17(5):304-308

32. Kipps S, Bahu T, Ong K, Ackland FM, Brown RS, Fox CT, et al. Current methods of transfer of young people with type 1 diabetes to adult services. Diabet Med. 2002;19(8):649-654

33. Pape L, Lämmermühle J, Oldhafer M, Blume C, Weiss R, Ahlenstiel T. Different models of transition to adult care after pediatric kidney transplantation: a comparative study. Pediatr Transplant. 2013:17(6):518-524

34. Annunziato RA, Baisley MC, Arrato N, et al. Strangers headed to a strange land? A pilot study of using a transition coordinator to improve transfer from pediatric to adult services. J Pediatr. 2013;163(6):1628-1633

35. Bent N, Tennant A, Swift T, Posnett J, Scuffham P, Chamberlain MA. Team approach versus ad hoc health services for young people with physical disabilities: a retrospective cohort study. Lancet. 2002;360(9342):1280-1286

36. Hankins JS, Osarogiagbon R, Adams-Graves P, McHugh L, Steele V, Smeltzer MP, et al. A transition pilot program for adolescents with sickle cell disease. J Pediatr Health Care. 2012;26(6):e45-49

37. Chaudhry SR, Keaton M, Nasr SZ. Evaluation of a cystic fibrosis transition program from pediatric to adult care. Pediatr Pulmonol. 2013:48(7):658-665

38. McDonagh JE, Southwood TR, Shaw KL British Society of Paediatric and Adolescent Rheumatology. The impact of a coordinated transitional care programme on adolescents with juvenile idiopathic arthritis Rheumatology (Oxford). 2007;46(1):161-168

39. Gholap N, Pillai M, Virmani S, et al. The Alphabet Strategy and standards of care in young adults with type 1 diabetes. $\mathrm{Br} J$ Diabetes Vasc Dis. 2006;6(4):168-170

40. Vidal M, Jansa $M$, Anguita $C$, et al. Impact of a special therapeutic education programme in patients transferred from a paediatric to an adult diabetes unit. Eur Diabetes Nurs. 2004;1(1):23-27

41. Andemariam B, Owarish-Gross J, Grady J Boruchov D, Thrall RS, Hagstrom JN. Identification of risk factors for an unsuccessful transition from pediatric to adult sickle cell disease care. Pediatr Blood Cancer. 2014;61(4):697-701

42. Betz CL, Smith K, Macias K. Testing the transition preparation training program: A randomized controlled trial. Intl J Child Adolesc Health. 2010;3(4):595-607

43. Greveson K, Morgan N, Furman M, Murray C. Attitudes and experiences of adolescents in an innovative IBD transition service Gastrointestinal Nurs. 2011;9(1):35-40

44. Huang JS, Terrones L, Tompane T, et al. Preparing adolescents with chronic disease for transition to adult care: a technology program Pediatrics. 2014;133(6). Available at: www. pediatrics.org/cgi/content/full/133/6/e1639

45. Van Walleghem N, Macdonald CA, Dean HJ. Evaluation of a systems navigator model for transition from pediatric to adult care for young adults with type 1 diabetes. Diabetes Care. 2008;31(8):1529-1530

46. Shaw KL, Southwood TR, McDonagh JE British Society of Paediatric and Adolescent Rheumatology. Young people's satisfaction of transitional care in adolescent rheumatology in the UK. Child Care Health Dev. 2007;33(4):368-379

47. Van Walleghem N, MacDonald CA, Dean HJ. Transition of care for young adults with type 1 and 2 diabetes. Pediatr Ann. 2012;41 (5):e16-e20 
48. Harden PN, Sherston SN. Optimal management of young adult transplant recipients: the role of integrated multidisciplinary care and peer support. Ann Saudi Med. 2013;33(5):489-491

49. McDonagh JE, Shaw KL, Southwood TR. Growing up and moving on in rheumatology: development and preliminary evaluation of a transitional care programme for a multicentre cohort of adolescents with juvenile idiopathic arthritis. J Child Health Care. 2006;10(1):22-42

50. Miller VA, Harris D. Measuring children's decision-making involvement regarding chronic illness management. J Pediatr Psychol. 2012;37 (3):292-306

51. Watson R, Parr JR, Joyce C, May C, Le Couteur AS. Models of transitional care for young people with complex health needs: a scoping review. Child Care Health Dev. 2011;37(6):780-791

52. Fletcher-Johnston M, Marshall SK, Straatman L. Healthcare transitions for adolescents with chronic life-threatening conditions using a Delphi method to identify research priorities for clinicians and academics in Canada. Child Care Health Dev. 2011;37(6):875-882

53. Lewis K. All grown up: moving from pediatric to adult diabetes care. Am J Med Sci. 2013;345(4):278-283

54. McLaughlin S, Bowering N, Crosby B, Neukirch J, Gollub E, Garneau D. Health care transition for adolescents with special health care needs: a report on the development and use of a clinical transition service. Rhode Island Med J. 2013;96(4):25-27

55. Persson A, Newman C. When HIV-positive children grow up: a critical analysis of the transition literature in developed countries. Qual Health Res. 2012;22(5):656-667

56. Dowshen N, D'Angelo L. Health care transition for youth living with HIV/AIDS. Pediatrics. 2011;128(4):762-771
57. Gilliam PP, Ellen JM, Leonard L, Kinsman S, Jevitt CM, Straub DM. Transition of adolescents with HIV to adult care: characteristics and current practices of the adolescent trials network for HIV/AIDS interventions. J Assoc Nurses AIDS Care. 2011;22(4):283-294

58. McDonagh JE, Kelly DA. The challenges and opportunities for transitional care research. Pediatr Transplant. 2010;14(6):688700

59. Viner R. Barriers and good practice in transition from paediatric to adult care. $J R$ Soc Med. 2001;94(suppl 40):2-4

60. Wojciechowski EA, Hurtig A, Dorn L. A natural history study of adolescents and young adults with sickle cell disease as they transfer to adult care: a need for case management services. J Pediatr Nurs. 2002; 17(1):18-27

61. Sawyer SM, Macnee S. Transition to adult health care for adolescents with spina bifida: research issues. Dev Disabil Res Rev. 2010;16(1):60-65

62. Beresford B. On the road to nowhere? Young disabled people and transition. Child Care Health Dev. 2004;30(6):581-587

63. Camfield PR, Gibson PA, Douglass LM. Strategies for transitioning to adult care for youth with Lennox-Gastaut syndrome and related disorders. Epilepsia. 2011;52 (suppl 5):21-27

64. Ferris ME, Mahan JD. Pediatric chronic kidney disease and the process of health care transition. Semin Nephrol. 2009;29(4):435-444

65. Annunziato RA, Hogan B, Barton C, et al. A translational and systemic approach to transferring liver transplant recipients from pediatric to adult-oriented care settings. Pediatr Transplant. 2010;14(7):823-829

66. Tuchman LK, Schwartz LA, Sawicki GS, Britto MT. Cystic fibrosis and transition to adult medical care. Pediatrics. 2010;125(3): 566-573

67. White PH, McManus MA, McAllister JW, Cooley WC. A primary care quality improvement approach to health care transition. Pediatr Ann. 2012;41(5):e1-e7

68. Grol R, Baker R, Moss F. Quality improvement research: understanding the science of change in health care. Qual Saf Health Care. 2002;11(2):110-111

69. Grol R, Baker R, Moss F. Quality Improvement Research: Understanding the Science of Change in Healthcare. London, UK: BMJ; 2004

70. Weitzman ER, Kaci L, Quinn M, Mandl KD. Helping high-risk youth move through highrisk periods: personally controlled health records for improving social and health care transitions. J Diabetes Sci Tech. 2011;5 (1): 47-54

71. While AE, Mullen J. Living with sickle cell disease: the perspective of young people. Br J Nurs. 2004;13(6):320-325

72. Nakhla M, Daneman D, Frank M, Guttmann A. Translating transition: a critical review of the diabetes literature. J Pediatr Endocrinol Metab. 2008;21(6):507-516

73. Stewart D, Stavness C, King G, Antle B, Law M. A critical appraisal of literature reviews about the transition to adulthood for youth with disabilities. Phys Occup Ther Pediatr. 2006;26(4):5-24

74. Crowley R, Wolfe I, Lock K, McKee M. Improving the transition between paediatric and adult healthcare: a systematic review. Arch Dis Child. 2011;96(6):548-553

75. Grote NK, Bledsoe SE. Predicting postpartum depressive symptoms in new mothers: the role of optimism and stress frequency during pregnancy. Health Soc Work. 2007;32 (2):107-118

(Continued from first page)

FUNDING: This project was supported by the Agency for Healthcare Research and Quality (contract number HHSA290-2012-00009-I). Dr Taylor was also supported by a career development award from the National Institute of Mental Health (K01 MH092598, Taylor, PI).

POTENTIAL CONFLICT OF INTEREST: Dr Taylor was supported by a career development award from the National Institute of Mental Health (K01 MH092598, Taylor, PI). The other authors have indicated they have no financial relationships relevant to this article to disclose. 